\title{
HERBASPIRILLUM-LIKE BACTERIA IN BANANA PLANTS
}

\author{
Olmar B. Weber ${ }^{*}$; Leonardo M. Cruz² ${\text { José I. Baldani³ }{ }^{3} \text { Johanna Döbereiner }}^{4}$
}

\begin{abstract}
${ }^{1}$ Embrapa - Centro Nacional de Pesquisa de Agroindústria Tropical, Fortaleza, CE, Brasil. ${ }^{2}$ Departamento de Bioquímica Universidade Federal do Paraná, Curitiba, PR, Brasil. ${ }^{3}$ Embrapa - Centro Nacional de Pesquisa de Agrobiologia, Seropédica, RJ, Brasil. ${ }^{4}$ In memoriam
\end{abstract}

Submitted: December 11, 2000; Returned to authors for corrections: March 12, 2001; Approved: September 03, 2001

\section{SHORT COMMUNICATION}

\begin{abstract}
Diazotrophic bacteria isolated from banana plants were characterized by morphological and physiological aspects. Three different groups of these plant-bacteria could be established. Two of them showed similarity to species of the Herbaspirillum genus. The third one was different because used only a few carbon substrates and produced water diffusible compounds that fluoresced under UV light. All three bacterial groups were thin rods with mono or bipolar flagella, presented negative reaction in Gram stain, showed catalase activity, were able to reduce nitrate and grew better in semi-solid $\mathrm{JNFb}$ medium at $31^{\circ} \mathrm{C}$. The nitrogenase activity was detected in semi-solid $\mathrm{N}$-free $\mathrm{JNFb}$ medium and expressed higher values when $\mathrm{pH}$ ranged from 6.5 to 7.0 (groups I and II) and 6.0 to 6.5 (group III). The diazotrophs isolated from banana plants were distinct from species of Herbaspirillum previously identified in gramineous plants.
\end{abstract}

Key words: Herbaspirillum, Herbaspirillum-like, Musa spp., microbial ecology

Over the last decades there has been a great interest in nitrogen fixing-bacteria associated to non-legumes, principally gramineous plants. The bacterial genera Azospirillum (10,27), Herbaspirillum $(2,3,13,23)$, Burkholderia $(4,16)$ and Gluconoacetobacter (8) were identified in these plants. In addition, diazotrophs also occurred in sweet potato (17), cassava (5), coffee (19), pineapple $(27,29)$ and banana plants (29).

The banana fruit crop is widely cultivated in tropical areas where high dosages of fertilizers are commonly applied. The biological nitrogen fixation could be an alternative for this crop system, once the plants are able to establish association with Herbaspirillum-like and Burkholderia related bacteria (29), which are not well known yet. This work aimed physiological and morphological characterization of the Herbaspirillum-like bacteria isolated from banana plants.

Among more than twenty-five strains of Herbaspirillumlike bacteria previously obtained (29), the representative diazotrophs from root samples of banana Caipira (BA12), stems of cultivars Butuhan (BA10) and Caipira (BA14, BA22), and leafs of cultivars Butuhan (BA11), Caipira (BA13), Prata Anã (BA22) and Maçã (BA87) were included in this study. All isolates were activated in semi-solid NFb medium (11) and grown on solid $\mathrm{NFb}$ and 79 + potato agar media (4) during three days at $30^{\circ} \mathrm{C}$. Controls (Bacillus sp. and Escherichia coli), grown on the last medium, and diazotrophs were evaluated for Gram stain, catalase and oxidase reactions (26). The nitrate reduction (7) with nitrite accumulation (21) of diazotrophs was evaluated after two days incubation in liquid DYGS medium (25) modified by adding $1 \mathrm{~g} / \mathrm{L}$ of malate and $\mathrm{pH}$ adjusted to 6.5. All isolates and a strain of Pseudomonas fluorescens were also evaluated for fluorescence of siderophores on King B medium under UV light after two days incubation at $30^{\circ} \mathrm{C}(20)$.

Nitrogenase activity of diazotrophic bacteria isolated from banana and type strains Herbaspirillum seropedicae $\mathrm{Z} 67^{\mathrm{T}}$ and Herbaspirillum rubrisubalbicans $\mathrm{M} 4^{\mathrm{T}}$ was evaluated in $\mathrm{JNFb}$

\footnotetext{
* Corresponding author. Mailing address: Rua Dra. Sara Mesquita, 2270, Planalto Pici, 60511-110, Fortaleza, CE, Brasil, Fax: (+55 85) 299-1833, E-mail: weber@cnpat.embrapa.br
} 
medium, at different $\mathrm{pH}$ and temperature of incubation (3). The inocula were prepared in liquid DYGS medium incubated for 24 $\mathrm{h}$ at $30^{\circ} \mathrm{C}$. Adjustment of $\mathrm{pH}(5.0,5.5,6.0,6.5,7.0$ and 7.5) was made by adding sterile $5 \% \mathrm{H}_{2} \mathrm{SO}_{4}$ or $10 \% \mathrm{KOH}$ to sterile semisolid $\mathrm{JNFb}$ medium. Three vials containing $5 \mathrm{~mL}$ of this medium were inoculated with $15 \mu \mathrm{L}$ aliquots of bacterial suspensions and incubated at $30^{\circ} \mathrm{C}$ during $52 \mathrm{~h}$. In the temperature experiment, the $\mathrm{pH}$ of semi-solid $\mathrm{JNFb}$ medium was adjusted to 6.0 and incubated for $48 \mathrm{~h}$ at $28,31,34,37$ and $41^{\circ} \mathrm{C}$. Nitrogenase activity in both experiments was determined by the $\mathrm{C}_{2} \mathrm{H}_{2}$ reduction method, after $1 \mathrm{~h}$ of incubation at $30^{\circ} \mathrm{C}$.

The cell morphology of isolates BA10, BA12 and BA22 grown on $79+$ potato agar medium during two days at $30^{\circ} \mathrm{C}$ was observed under transmission electron microscopy (TEM) ZEISS M-900 operated at $80 \mathrm{~kW}$. The cells were fixed on silver $200 \mathrm{Hex}$ Mesh grids coated with Formvar and stained with 5\% uranil acetate solution (22).

The capability of isolates BA10, BA11, BA12, BA13, BA22, BA23 and $Z 67^{\mathrm{T}}$ to survive in soil was also evaluated. All strains were grown in liquid DYGS medium for $24 \mathrm{~h}$ at $30^{\circ} \mathrm{C}$, centrifuged for $20 \mathrm{~min}$ at $4.000 \mathrm{rpm}$ and suspended in saline solution to 1.0 $\mathrm{OD}$ at $600 \mathrm{~nm}$. Aliquots $(1 \mathrm{~mL})$ of bacterial suspensions were inoculated into $10 \mathrm{~g}$ samples of red-yellow podzolic soil (typic Hapludult). The soil samples were moistened to $70 \%$ field capacity and incubated at $30^{\circ} \mathrm{C}$. Three samples of each soil treatment were harvested at different times ( $1 \mathrm{~h}$ and 8, 16 and 24 days) and submitted to estimation of MPN diazotrophs, according to Döbereiner et al. (11).
On solid NFb medium, the banana plant Herbaspirillumlike bacteria formed colonies with blue centers. In semi-solid Nfree $\mathrm{JNFb}$ medium, they formed veil-like membranes near the surface. All isolates were Gram negative, catalase and oxidase positive and were able to reduce nitrate in liquid DYGS medium similarly to $H$. seropedicae (3) and $H$. rubrisubalbicans $(2,23)$.

The three bacterial groups were able to form good pellicles in semi-solid media containing D-mannitol, D-sorbitol, glycerol, citrate, $\alpha$-ketoglutarate, succinate, fumarate and malate as sole carbon source. The isolates of group I were able to use $\mathrm{N}$ acetyl-glucosamine, those of group II used meso-erythritol + $\mathrm{NH}_{4}$, and those of group III were unable to use these carbon sources in semi-solid media (Table 1). The characteristic observed in isolates of group I was similar to that described for $H$. seropedicae (3), while those of group II was similar to $H$. rubrisubalbicans (2). However, differently from these species of Herbaspirillum, the two first groups were able to use Ltartrate as sole carbon source. The groups I and II had the same pattern as H. rubrisubalbicans in ARDRA analysis and showed phylogenetic relationship among the Herbaspirillum cluster (9). Both bacterial groups failed to react with species-specific oligonucleotide probes (29) and may represent new Herbaspirillum species.

The isolates from group III were able to produce blue fluorescent compounds on King B medium under UV light (Table 1), which has never been observed with diazotrophs before. The pigment production has been detected in plant pathogenic Pseudomonas species (18), Burkholderia cepacia (14) and

Table 1. Phenotypic differences of Herbaspirillum-like bacteria from banana plants and species of Herbaspirillum genus.

\begin{tabular}{|c|c|c|c|c|c|}
\hline \multirow{2}{*}{ Characteristic } & \multicolumn{3}{|c|}{ Groups of diazotrophs } & \multicolumn{2}{|c|}{ Herbaspirillum } \\
\hline & $\mathbf{I}$ & II & III & Z67T & M4T \\
\hline Rod shape ${ }^{a}$ & Curved & Curved & Straight & Curved & Curved \\
\hline Size $\mu \mathrm{m}$ on batata+79) medium ${ }^{\mathrm{a}}$ & $2.0 \times 0.6$ to 0.7 & $1.9 \times 0.7$ to 0.8 & $1.8 \times 0.6$ to 0.8 & Un & Un \\
\hline $\begin{array}{l}\text { Flagellum } \\
\text { mono, } \\
\text { bipolar }^{\text {a }}\end{array}$ & $\begin{array}{l}0 \text { to } 3 \\
+ \\
+\end{array}$ & $\begin{array}{l}0 \text { to } 3 \\
+ \\
+\end{array}$ & $\begin{array}{l}0 \text { to } 1 \\
+ \\
-\end{array}$ & Un & Un \\
\hline Fluorescence on King B mediumb ${ }^{b}$ & - & - & + & - & - \\
\hline $\mathrm{pH}$ in $\mathrm{JNFb}$ semi-solid medium ${ }^{\mathrm{c}}$ & 6.5 to 7.0 & 6.0 to 7.0 & 6.0 to 6.5 & 6.0 to 7.0 & 6.0 to 7.0 \\
\hline Soil Surviving for 24 days $^{\mathrm{d}}$ & Poor & $\mathrm{Nd}$ & $\mathrm{Nd}$ & Poor & Un \\
\hline \multicolumn{6}{|c|}{ Use of carbon source in semi-solid mediac } \\
\hline D-Glucose & + & + & - & + & + \\
\hline L-arabinose & + & + & - & + & + \\
\hline Rhamnose & - & - & - & + & - \\
\hline L-tartrate & + & + & - & - & - \\
\hline Meso-erythritol $+\mathrm{NH}_{4}$ & - & + & - & - & + \\
\hline $\mathrm{N}$-acetylglucosamine & + & - & - & + & - \\
\hline
\end{tabular}

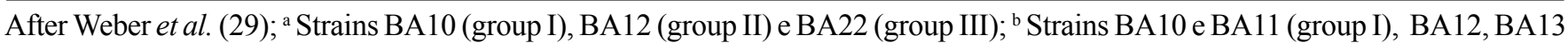

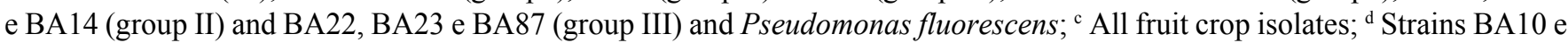
BA11 (group I), BA12, BA13 (group II) and BA22, BA23 (group III); Characteristics undetermined (Un) or no-detected (Nd). 


\section{GROUPI}

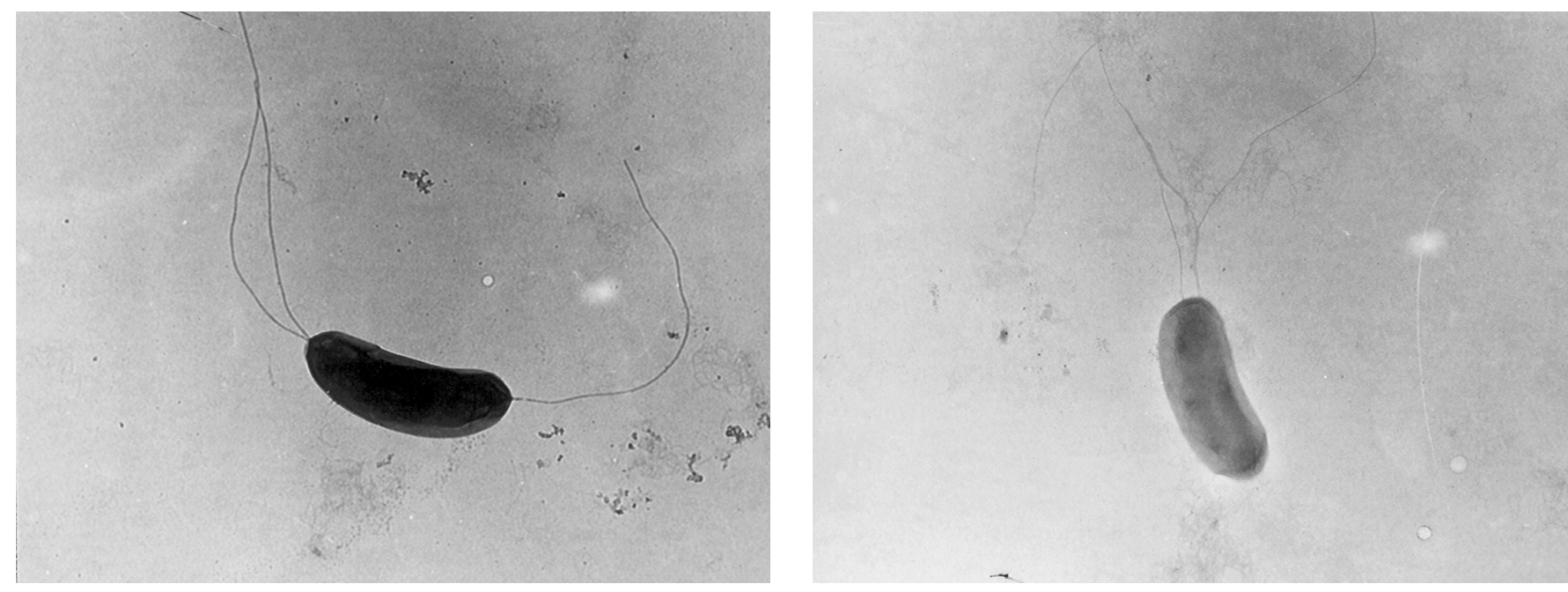

GROUPII

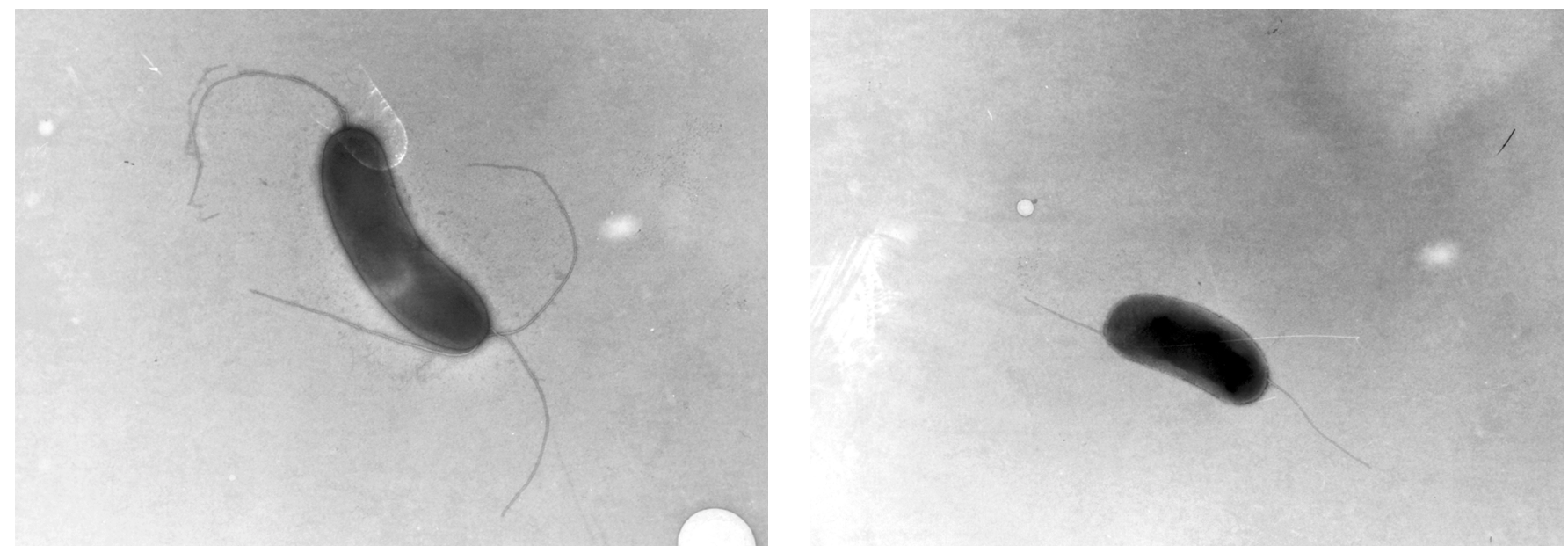

GROUP III

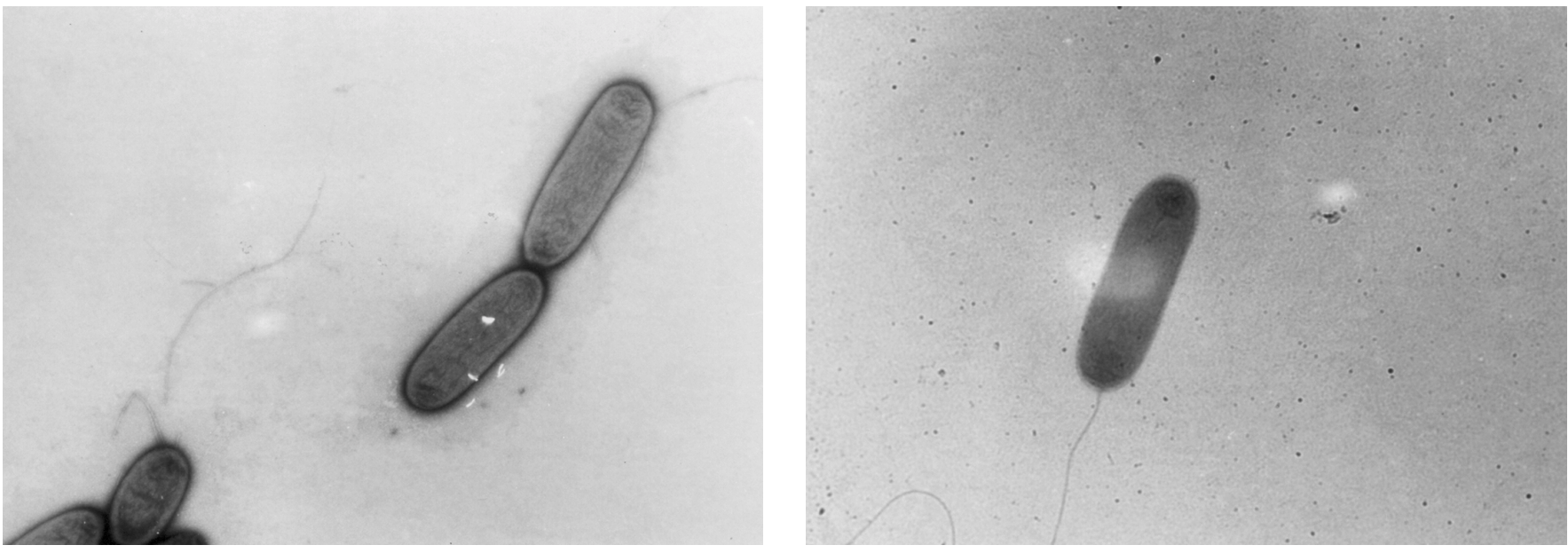

Figure 1. Negative staining of Herbaspirillum-like bacteria from banana plants. Young cells from isolates: BA10 (group I), BA12 (group II) and BA22 (group III) on $79+$ potato medium. Bar with $<==>1.1 \mu \mathrm{m}$. 
members of Comamonadaceae family (30) without nitrogenase activity. The phylogenetic relationship of ARDRA types from the bacterial group III with the Comamonadaceae was observed (9). The pigment production was a characteristic described for Hidrogenophaga, Xilophilus and Brachymonas genera (30).

The bacterial group III may represent a new genus of diazotrophic bacteria. The representative isolate (BA22) from the group was a straight rod ( $1.8 \mu \mathrm{m}$ long and 0.6 to $0.8 \mu \mathrm{m}$ wide) with only one polar flagellum (Table 1 and Fig. 1), distinguishing it from the known species of Herbaspirillum genus identified in gramineous plants. Short rods with one polar flagellum were observed in $\mathrm{N}_{2}$-fixing Pseudomonas sp. isolated from rhizosphere of Oryza sativa (6) and described for Brachymonas, Hidrogenophaga and Xilophilus genera (30). However, these bacteria fermented sucrose, except the Brachymonas genus, which occurred in activated sludge (30). Another dinitrogenfixing Pseudomonas sp., isolated from Deschampsia caespitosa, was a slightly curved rod and presented tuff polar flagella (15).

The bacterial groups I and II presented curved rod-shaped cells (Table 1 and Fig. 1) and were mobile in water, with increased movement next to air bubbles. The isolate BA10 (representative from group I) measured $2.0 \mu \mathrm{m}$ by 0.6 to $0.7 \mu \mathrm{m}$ and presented one to three polar flagella or $1+1$ and $1+2$ flagella in both cell poles, similarly to $H$. seropedicae (3). The isolate BA12 (representative of group II) presented $1.9 \mu \mathrm{m}$ by 0.7 to $0.8 \mu \mathrm{m}$, with flagella similar to isolate BA10. Bipolar flagella had never been observed in strains of $H$. rubrisubalbicans (23).

Isolates from groups I and II presented higher nitrogenase activity in $\mathrm{N}$-free $\mathrm{JNFb}$ medium when the $\mathrm{pH}$ ranged from 6.5 to 7.0 (Fig. 2) and the temperature was $31^{\circ} \mathrm{C}$ (Fig. 3). No nitrogenase activity was detected in semi-solid $\mathrm{JNFb}$ medium at $41^{\circ} \mathrm{C}$. The optimal $\mathrm{pH}$ value for $H$. seropedicae ranged from 5.0 to 8.0 in malate nitrogen-free semi-solid medium, at $34^{\circ} \mathrm{C}(3)$. Concerning the bacterial group III, we detected higher nitrogenase activity when the $\mathrm{pH}$ ranged from 6,0 to 6.5 (Fig. 2) and temperature of $31^{\circ} \mathrm{C}$ (Fig. 3). The dinitrogen-fixing Pseudomonas sp. from rice plants grew better on semi-solid NFb medium with $0.5 \%$ glucose and $0.01 \%$ yeast extract, with $\mathrm{pH}$ ranging from 6.5 to 7.0 and temperature ranging from 30 to $35^{\circ} \mathrm{C}(28)$.

The three bacterial groups survived poorly in a red-yellow podzolic soil. After three weeks, bacteria from groups II and III were no more detectable in the soil while less than $10^{1}$ bacteria/g was observed for bacteria from group I. The poor surviving capability was also observed for bacteria of Herbaspirillum genus (23) and for Burkholderia brasilensis (4) and could be an indication of endophytic diazotrophs, as related by Döbereiner (12) and Baldani et al. (1). Further, the populations $\left(10^{2}\right.$ to $10^{3}$ bacteria per gram) of native Azospirillum brasilense and Azospirillum lipoferum present in the control soil showed no decrease during the incubation time. This genus of diazotrophic bacteria has been originally isolated from rhizosphere of gramineous plant (12) and behaves as facultative endophytic bacterium (1).

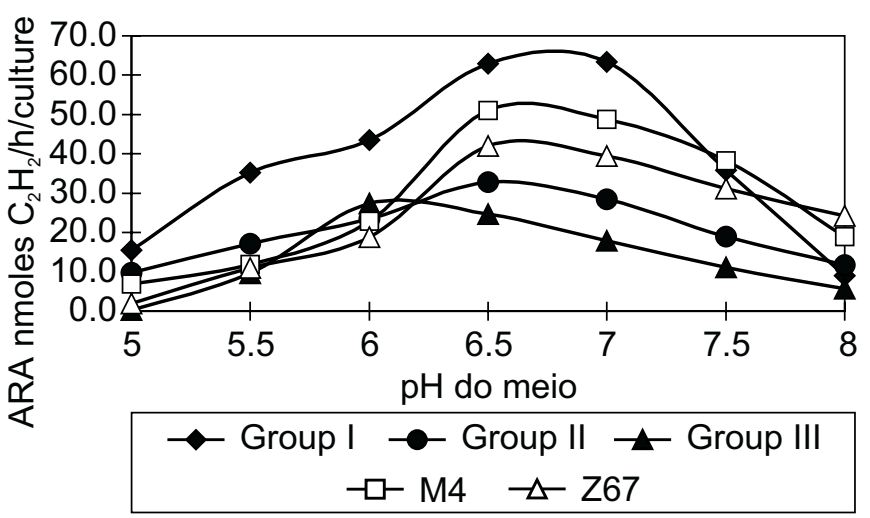

Figure 2. Effect of initial $\mathrm{pH}$ on the nitrogenase activities of log-phase cultures of Herbaspirillum-like bacteria from banana plants and type strains $\mathrm{Z} 67^{\mathrm{T}}$ and $\mathrm{M} 4^{\mathrm{T}}$. Average of isolates BA10 and BA11 (group I), BA12, BA13 and BA14 (group II) and BA22, BA23 and BA87 (group III).

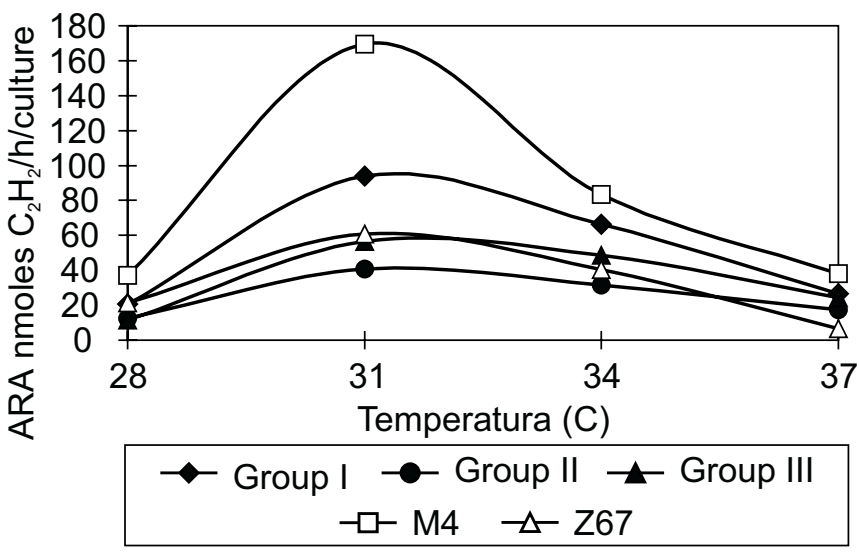

Figure 3. Effect of incubation temperature on the nitrogenase activities of log-phase cultures of Herbaspirillum-like bacteria from banana plants and type strains $267^{\mathrm{T}}$ and $\mathrm{M} 4^{\mathrm{T}}$. Average of isolates BA10 and BA11 (group I), BA12, BA13 and BA14 (group II) and BA22, BA23 and BA87 (group III).

\section{ACKNOWLEDGEMENTS}

The authors would like to express deep appreciation to Dr. Francisco Freire of Embrapa Tropical Agroindustry, for critically reviewing the manuscript.

\section{RESUMO}

\section{Bactérias do tipo Herbaspirillum em bananeira}

Bactérias diazotróficas do tipo Herbaspirillum isoladas de bananeiras foram avaliadas pelas características morfológicas 
e fisiológicas de crescimento. Três grupos de bactérias foram estabelecidos, sendo dois relacionados às espécies de Herbaspirillum e diferentemente o terceiro grupo apresentou habilidade em crescer com poucos substratos orgânicos e produziu substância fluorescente em meio B de King. As bactérias dos três grupos eram bastonetes com flagelos mono ou bipolares, apresentaram reação negativa na coloração de Gram, expressaram atividade de catalase e oxidade, foram capazes de reduzir o nitrato e cresceram melhor em meio JNFb semisólido incubado a $31^{\circ} \mathrm{C}$. A atividade da nitrogenase, medida através da atividade de redução de acetileno, foi máxima em meio JNFb semi-sólido, após o ajuste de $\mathrm{pH}$ na faixa de 6,0 a 7,0 (grupos I e II) e 5,5 a 6,5 (grupo III). As bactérias diazotróficas associadas às bananeiras são diferentes das espécies de Herbaspirillum anteriormente identificadas em gramíneas.

Palavras-chave: Herbaspirillum, bactérias tipo Herbaspirillum, Musa spp., ecologia microbiana

\section{REFERENCES}

1. Baldani, J.I.; Caruso, L.; Baldani, V.L.D.; Goi, S.R.; Döbereiner, J. Recent advances in BNF with non-legume plants. Soil Biol. Biochem. 29:911-922, 1997.

2. Baldani, J.I.; Pot, B.; Kirchhof, G.; Falsen, E.; Baldani, V.L.D.; Olivares, F.L.; Hoste, Kersters, K.; Hartmann, A.; Gillis, M.; Döbereiner, J. Emended description of Herbaspirillum; inclusion of [Pseudomonas] rubrisubalbicans, a mild plant pathogen, as Herbaspirillum rubrisubalbicans comb. nov.; and classification of a group of clinical isolates (EF group 1) as Herbaspirillum species 3. Int. J. Sys. Bacteriol., 46:802-810, 1996.

3. Baldani, J.I.; Baldani, V.L.D.; Seldin, L.; Döbereiner, J. Characterization of Herbaspirillum seropedicae gen. nov., a root-associated nitrogenfixing bacterium. Int. J. Syst. Bacteriol., 36:86-93, 1986.

4. Baldani, V.L.D. Efeito da inoculação de Herbaspirillum spp. no processo de colonização e infecção de plantas de arroz, e ocorrência e caracterização parcial de uma nova bactéria diazotrófica. UFRRJ, Seropédica, 1996. 238p. (D.Sc. thesis)

5. Balota, E.L. Interação de bactérias diazotróficas e fungos micorrizicos arbusculares na cultura da mandioca (Manihot esculenta Crants). UFRRJ, Itaguaí, 1994. 281p. (D.Sc. thesis).

6. Barraquio, W.L.; Ladha, J.K.; Watanabe, I. Isolation and identification of $\mathrm{N}_{2}$-fixing Pseudomonas associated with wetland rice. Can. J. Microbiol., 29:867-873, 1983.

7. Cataldo, D.A.; Haroon, M.; Shrader, L.E.; Youngs, V.L. Rapid colorimetric determination of nitrate in plant tissue by nitration of salicilic acid. Com. Soil Sci. Pl. An., 6:71-80, 1975.

8. Cavalcante, V.A.; Dobereiner, J. A new acid-tolerant nitrogen-fixing bacterium associated with sugarcane. Plant and Soil, 108:23-31, 1988.

9. Cruz, L.M.; Souza, E.M.; Weber, O.B.; Baldani, J.I.; Döbereiner, J.; Pedrosa, F.O. 16S rDNA characterization of new nitrogen-fixing bacteria from Banana (Musa spp.) and pineapple (Ananas comosus (L) Merril). Appl. Environ. Microbiol., 67:2375-2379, 2001.

10. Döbereiner J. Fixação de nitrogênio em gramíneas. Rev. brasi. Ci. Solo, 1:1-54, 1977.

11. Döbereiner J.; Baldani V.L.D.; Baldani J.I. Como isolar e identificar bactérias diazotróficas de plantas não-leguminosas. Embrapa-SPI, Brasília, 1995. 60p.

12. Döbereiner, J. History and new perspectives of diazotrophs in association with non-leguminous plants. Symbiosis, 13:1-13, 1992

13. Gillis, M.; Döbereiner, J.; Pot, B.; Good, M.; Falsen, E.; Hoste, B.; Reinhold, B.; Kersters, K. Taxonomic relationships between
(Pseudomonas) rubrisubalbicans, some clinical isolates (EF group I), Herbaspirillum seropedicae and (Aquaspirillum) autotrophicum. Dev. Plant and Soil Sci., 48:293-294, 1991.

14. Gillis. M.; Van, T.V.; Bardin, R.; Goor, M.; Hebbar, P.; Willems, A.; Segers, P.; Kersters, K.; Heulin, T.; Fernandez, M.P. Polyphasic taxonomy in genus Burkholderia leading to an emended description of the genus and proposition of Burkholderia vietnamiensis sp: nov. for $\mathrm{N}_{2}$-fixing isolates from rice in Vietnam. Int. J. Syst. Bacteriol., 45:274-289, 1995.

15. Haahtela, K.; Helander, I.; Nurmiaho-Lassila, E.L.; Sundman, V. Morphological and physiological characteristics and lipopolyssaccharide composition of $\mathrm{N}_{2}$-fixing $\left(\mathrm{C}_{2} \mathrm{H}_{2}\right.$-reducing $)$ root-associated Pseudomonas sp. Can. J. Microbiol., 29:874-880, 1983.

16. Hartmann, A.; Baldani, J.I.; Kirchhof, G.; Assmus, B.; Hutzler, P.; Springer, N.; Ludwig, G.W.; Baldani, V.L.; Döbereiner, J. Taxonomic and ecological studies of diazotrophic rhizosphere bacteria phylogenetic probes. In: Fendrik, I.; Del Gallo, M.; Vanderleyden, J.; Zamaroczy, M. (Eds). Azospirillum VI and related microorganisms: genetics, physiology and ecology. Springer Verlag, New York, 1995. p.416-427.

17. Hill, W.A.; Bacon Hill, P.; Crossman, S.M.; Stevens, C. Characterization of $\mathrm{N}_{2}$-fixing bacteria associated with sweet potato roots. Can. J. Microbiol., 29:860-862, 1983.

18. Holt, J.G.; Krieg, N.R.; Sneath, P.H.A.; Staley, J.T.; Williams, S.T. Bergey's manual of determinative bacteriology, 9.ed. Williams \& Williams, Baltimore, 1994. 787p.

19. Jiménez Salgado, T.; Fuentes Ramires, L.E.; Tapia Hernandes, A.; Mascarua Esperanza, M.A.; Martinez Romero, E.; Caballero Mellado, O. Coffea arabica L., a new host plant for Acetobacter diazotrophicus and isolation of the nitrogen-fixing-acetobacteria. Appl. Environ. Microbiol., 63:3676-3683, 1998.

20. King, E.O.; Ward, M.K.; Raney, D.E. Two simple media for the demonstration of pyocyanin and fluorescein. J. Lab. Cl. Med., 44:301-307, 1954.

21. Neyra, C.A.; Döbereiner, J.; Lalande, R.; Knowles, R. Denitrification by $\mathrm{N}_{2}$-fixing Spirillum lipoferum. Can. J. Microbiol., 23:300-305, 1976.

22. Olivares, F.L. Taxonomia, ecologia e mecanismos envolvidos na infecção e colonização de plantas de cana-de-açúcar (Saccharum sp. híbrido) por bactérias endofiticas do gênero Herbaspirillum. UFRRJ, Seropédica, 1997. 344p. (D.Sc. thesis).

23. Olivares, F.L.; Baldani, V.L.D.; Reis, V.M.; Baldani J.I.; Döbereiner, $\mathrm{J}$. Occurrence of the endophytic diazotrophs Herbaspirillum spp. in roots, stems, and leaves, predominantly of Gramineae. Biol. Fertil. Soils., 21:197-200, 1996.

24. Patriquim, D.G.; Döbereiner, J. Light microscopy observation of tetrazolium reducing bacteria in endorhizosphere of maise and other grasses in Brazil. Can. J. Microbiol., 24:734-742, 1978.

25. Rodrigues Neto, J.; Malavolta Jr., V.A.; Victor, O. Meio simples para isolamento e cultivo de Xanthomonas campestris pv. citri Tipo B. Sum. Phytol., 2:16-16, 1986.

26. Smibert, R.; Krieg, N.R. Genaral characterization. In: Gerhard, P.; Murray, R.G.E.; Costilow, R.N.; Nester, E.W.; Wood, W.A.; Krieg, N.R.; Phillips, G.B. (ed.). Manual of methods for general bacteriology. Am. Soc. Microbiol, Washington, 1981. p409-443.

27. Tapia-Hernandez, A.; Bustillos-Cristales, M.R.; Jimenez-Salgado, T.; Caballero-Mellado, J.; Fuentes-Ramírez, L.E. Natural endophytic occurrence of Acetobacter diazotrophicus in pineapple plants. Microbial Ecol., 39:49-55, 2000.

28. Watanabe, I.; So, R.; Ladha, J.K. A new nitrogen-fixing species of pseudomonad: Pseudomonas diazotrophicus sp. nov. isolated from the root of wetland rice. Can. J. Microbiol., 33:670-678, 1987.

29. Weber, O.B.; Baldani, V.L.D.; Teixeira, K.R.S.; Kirchhof, G.; Baldani, J.I.; Döbereiner, J. Isolation and characterization of diazotrophic bacteria from banana and pineapple plants. Plant Soil., 210:103-213, 1999.

30. Wen, A.; Fegan, M.; Hayward, C.; Chakraborty, S.; Sly, L.I. Phylogenetic relationships among members of the Comamonadaceae, and description of Delftia acidovorans (den Dooren de Jong 1926 and Tamaoka et al. 1987) gen. Nov., comb.nov. Int. J Sys. Bacteriol., 49:567-576, 1999 . 